REGARDS

SUR L'ECONOMIE ALLEMANDE

BULLETIN ECONOMIQUE DU CRAC

\section{Regards sur l'économie allemande}

Bulletin économique du CIRAC

$109 \mid 2013$

Varia

\title{
Droit communautaire
}

HERRMANN Christoph, Europäisches Währungsrecht

\section{CpenEdition}

\section{Journals}

Édition électronique

URL : http://journals.openedition.org/rea/4570

DOI : $10.4000 /$ rea. 4570

ISSN : 1965-0787

Éditeur

CIRAC

Édition imprimée

Date de publication : 4 juillet 2013

ISSN : 1156-8992

\section{Référence électronique}

« Droit communautaire », Regards sur l'économie allemande [En ligne], 109 | juillet 2013, mis en ligne le

19 juillet 2013, consulté le 22 septembre 2020. URL : http://journals.openedition.org/rea/4570 ; DOI https://doi.org/10.4000/rea.4570

Ce document a été généré automatiquement le 22 septembre 2020.

(c) CIRAC 


\section{Droit communautaire}

HERRMANN Christoph, Europäisches Währungsrecht

\section{RÉFÉRENCE}

HERRMANN Christoph, Europäisches Währungsrecht, Verlag C.H. Beck, Munich, 2013, $484 \mathrm{p}$.

1 Ce précis rassemble les textes législatifs - Pacte euro plus, mécanismes FESF et MES créés par l'Union européenne depuis 2008. Il les replace dans le contexte du droit monétaire international (FMI, GATT, OMC) et des principaux traités et règlements européens (TFUE, TUE, Pacte de stabilité et de croissance), tout en rappelant le rôle de la $\mathrm{BCE}$ dans le système monétaire européen. A quand une édition 'pour tous' de ces textes en France? (rm/sh) 